\title{
Anti-amnestic Activity of Pseudocoptisine from Corydalis Tuber
}

\author{
Tran Manh Hung, ${ }^{a}$ Tran Minh NGOc, ${ }^{a}$ Ui Joung Youn, ${ }^{a}$ Byung Sun Min,,${ }^{b}$ MinKyun NA, ${ }^{a}$ \\ Phuong Thien ThuOnG, ${ }^{a}$ and KiHwan $\mathrm{BAE}^{*, a}$ \\ ${ }^{a}$ College of Pharmacy, Chungnam National University; Daejeon 305-764, Korea: and ${ }^{b}$ College of Pharmacy, Catholic \\ University of Daegu; Gyeongsan 712-702, Korea. \\ Received September 20, 2007; accepted October 28, 2007; published online November 5, 2007
}

\begin{abstract}
Pseudocoptisine, a quaternary alkaloid with benzylisoquinoline skeleton, was isolated from Corydalis Tuber, one of the important medicinal plants in traditional medicine. Pseudocoptisine inhibited acetylcholinesterase (AChE) activity in a dose-dependent manner, and the concentration required for $50 \%$ inhibition was $12.8 \mu \mathrm{M}$. In further study, the anti-amnesic activities of pseudocoptisine in mice on the learning and memory impairments induced by scopolamine $(1.0 \mathrm{mg} / \mathrm{kg}$, i.p.) were examined. This alkaloid $(2.0 \mathrm{mg} / \mathrm{kg}$, p.o. $)$ administration significantly reversed cognitive impairments in mice by passive avoidance test $(p<0.05)$. It also reduced escape latencies in training trials and prolonged swimming times in the target quadrant during the probe trial in the water maze task $(p<0.05)$. These results indicate that pseudocoptisine has anti-cholinesterase and antiamnesic activities that may be useful for cognitive impairment treatment.
\end{abstract}

Key words Corydalis Tuber; pseudocoptisine; alzheimer's disease; acetylcholinesterase; amnesic

Alzheimer's disease (AD) is the most common age-related neurodegenerative disease with many cognitive and neuropsychiatric manifestations that result in progressive disability and eventual incapacitation. AD is characterized by the presence of excessive amounts of neuritic plaques containing amyloid $\beta$ protein and loss of cholinergic markers in brain. Loss of cholinergic cells, particularly in the basal forebrain, is accompanied by loss of the neurotransmitter acetylcholine. ${ }^{1)}$ The cause of $\mathrm{AD}$ is not known clearly. Recently, the mainstay treatments for $\mathrm{AD}$ are acetylcholinesterase (AChE) inhibitors, which increase the availability of acetylcholine at cholinergic synapses. AChE inhibitors from general chemical classes such as physostigmine, tacrine, galantamine and heptylphysostigmine have been tested for the symptomatic treatment of AD. ${ }^{2)}$ However, non-selectivity of these drugs, their limited efficacy, and poor bioavailability, adverse cholinergic side effects in the periphery, narrow therapeutic ranges and hepatotoxicity are among the severe limitations to their therapeutic success. ${ }^{3)}$ In addition, the effect on the activities of AChE not associated with nervous transmission is more difficult to predict, but inhibitors of these aspects of its function have been predicted as worth exploring in the search for novel drugs. ${ }^{4)}$

In our screening program to search for AChE inhibitors from plants, a crude $70 \%$ ethanol extract of tuber of Corydalis turtschaninovii Besser forma yanhusuo (Corydalis Tuber, Papaveraceae family) exhibited significant AChE inhibitory activity $(>70 \%$ at $50 \mu \mathrm{g} / \mathrm{ml})$. Corydalis Tuber has been used in traditional medicine in the treatment of gastric, duodenal ulcer, cardiac arrhythmia disease, rheumatism, dysmenorrheal, ${ }^{5,6)}$ and memory dysfunction in folk medicine. ${ }^{7-9)}$ The tuber contains several pharmacologically important alkaloids such as corydaline, berberine, protopine, palmatine, corynoline ${ }^{10-13)}$ However, few studies have been specifically investigated the ability of active components on memory dysfunction. We report herein the investigations regarding the active principal in AChE inhibitory activity and anti-amnesic effect of pseudocoptisine isolated from this tuber.

\section{MATERIALS AND METHODS}

Plant Material The tuber of Corydalis turtschaninovii Besser forma yanhusuo (Papaveraceae) was purchased at Yuseong oriental herbarium market in Daejeon, Korea on September 2006. The plant was botanically identified by Professor KiHwan Bae, College of Pharmacy, Chungnam National University, where the voucher specimens was deposited (CNU-00124).

Extraction and Isolation The tuber of Corydalis turtschaninovii Besser forma yanhusuo $(5 \mathrm{~kg})$ were dried and extracted with $70 \% \mathrm{EtOH}$. The solution was evaporated and residue $(240 \mathrm{~g})$ was diluted with $3 \%$ aqueous $\mathrm{HCl}$ to give acidic solution and insoluble part. The acidic $\mathrm{H}_{2} \mathrm{O}$ layer was then basified with aqueous $\mathrm{NH}_{4} \mathrm{OH}(\mathrm{pH}$ 9) to produce frees bases, and then extracted with $\mathrm{CH}_{2} \mathrm{Cl}_{2}$, resulting in organic phase (48g, Part A) and aqueous phase (Part B). Part B, which contented quaternary alkaloids, was subjected to Dianion column chromatography using step gradient elution with $\mathrm{H}_{2} \mathrm{O}: \mathrm{MeOH}\left(\mathrm{H}_{2} \mathrm{O} \rightarrow 30 \% \mathrm{MeOH}, 40 \rightarrow 70 \% \mathrm{MeOH}\right.$, and $80 \rightarrow 100 \% \mathrm{MeOH})$ to give three fractions $(\mathrm{B} 1-\mathrm{B} 3)$. Fraction B2 was applied to MCI gel column and eluted with $\mathrm{H}_{2} \mathrm{O}: \mathrm{MeOH}(1: 1)$ to give $\mathrm{B} 2.1-\mathrm{B} 2.5$. B2.1 was re-subjected to MCI gel CHP20 column chromatography using $2 \%$ $\mathrm{AcOH}: \mathrm{MeOH}$ and further applied to MPLC system: ODSS-50 column $(11 \times 300 \mathrm{~mm})$, UV $245 \mathrm{~nm}$, flow rate $2 \mathrm{ml} / \mathrm{min}$, using $\mathrm{H}_{2} \mathrm{O}: \mathrm{MeOH}: \mathrm{NH}_{4} \mathrm{OH}(1: 4: 0.05)$ to afford pseudocoptisine, $38 \mathrm{mg}$.

Pseudocoptisine: Brown powder, EI-MS $\mathrm{m} / \mathrm{z}$ 320.09, $\mathrm{C}_{19} \mathrm{H}_{14} \mathrm{NO}_{4} .{ }^{1} \mathrm{H}-\mathrm{NMR}\left(300 \mathrm{MHz}, \mathrm{CDCl}_{3}\right) \delta \mathrm{ppm}: 9.72(1 \mathrm{H}, \mathrm{s}$, $\mathrm{H}-8), 8.67(1 \mathrm{H}, \mathrm{s}, \mathrm{H}-13), 7.84(1 \mathrm{H}, \mathrm{s}, \mathrm{H}-9), 7.84(1 \mathrm{H}, \mathrm{s}, \mathrm{H}-$ 1), $7.59(1 \mathrm{H}, \mathrm{s}, \mathrm{H}-12), 6.91(1 \mathrm{H}, \mathrm{s}, \mathrm{H}-4), 6.91(2 \mathrm{H}, \mathrm{s}, \mathrm{H}-15)$, $6.10(2 \mathrm{H}, \mathrm{s}, \mathrm{H}-16), 4.88(2 \mathrm{H}, \mathrm{t}, J=6.0 \mathrm{~Hz}, \mathrm{H}-6), 3.24(2 \mathrm{H}, \mathrm{t}$, $J=6.0 \mathrm{~Hz}) \cdot{ }^{13} \mathrm{C}-\mathrm{NMR}\left(75 \mathrm{MHz}, \mathrm{CDCl}_{3}\right) \delta \mathrm{ppm}: 28.1(\mathrm{C}-5)$, 57.1 (C-6), 103.5 (C-15), 105.9 (C-16), 106.3 (C-4), 109.3 (C-9), 113.5 (C-12), 121.5 (C-8a), 122.3 (C-12a), 122.5 (C1), 123.0 (C-13), 131.3 (C-4a), 134.2 (C-14a), 138.8 (C-2), 144.9 (C-8), 145.6 (C-10), 149.1 (C-11), 149.8 (C-3), 152.1 (C-14).

Animals Male ICR mice, weighing 20-25 g, were pur- 
chased from the Daehan Biolink Co., Ltd. Animals were housed 5 or 6 per cage, allowed access to water and food $a d$ libitum, and maintained in a constant temperature $\left(23 \pm 1^{\circ} \mathrm{C}\right)$ and humidity $(60 \pm 10 \%)$ environment under a 12-h light/dark cycle (light on $07.30-19.30 \mathrm{~h}$ ). Animal treatment and maintenance were carried out in accordance with the Principle of Laboratory Animal Care (NIH publication No. 85-23, revised 1985) and the Animal Care and Use Guidelines of Chungnam National University, Korea.

In Vitro Assay of Brain Acetylcholinesterase Adult Sprague-Dawley male rats, weighing $200-250$ g, were supplied by Daehan Biolink Co., Ltd. Rats were decapitated; the brain was rapidly dissected on ice and then homogenized in five volumes of cold $75 \mathrm{~mm}$ sodium phosphate buffer, $\mathrm{pH} 7.4$. Homogenates were centrifuged at $1000 \times \boldsymbol{g}$ for $10 \mathrm{~min}$ at $4{ }^{\circ} \mathrm{C}$; supernatants selected as acetylcholinesterase sources were divided into aliquots and stored at $-20^{\circ} \mathrm{C}$. Acetylcholinesterase activity was measured by the principle of the Ellman method with some modification. ${ }^{14)}$ Pseudocoptisine was initially dissolved in $0.02 \%$ dimethyl sulfoxide (DMSO) and diluted to various concentrations in sodium phosphate buffer (100 mm, $\mathrm{pH} 8.0)$ immediately before use. An aliquot of diluted compound was then mixed with buffer, acetylthiocholine iodide solution $(75 \mathrm{~mm})$ and buffered Ellman's reagent $(10 \mathrm{~mm}$ 5,5'-dithio-bis[2-nitrobenzoic acid] and $15 \mathrm{~mm}$ sodium bicarbonate), reacted at room temperature for $30 \mathrm{~min}$. Absorbance was measured at $410 \mathrm{~nm}$ immediately after adding the enzyme source to the reaction mixtures using a spectrophotometer (Shimadzu UV-1240, Tokyo, Japan). Readings were taken at $30 \mathrm{~s}$ intervals for $5 \mathrm{~min}$. The concentration of compound required inhibiting acetylcholinesterase activity by $50 \%\left(\mathrm{IC}_{50}\right)$. Tacrine was used as a positive control.

Passive Avoidance Task Passive avoidance task was carried out in identical illuminated and nonilluminated boxes. The illuminated compartment $(20 \times 20 \times 20 \mathrm{~cm})$ contained an $100 \mathrm{~W}$ bulb, and the floor of nonilluminated compartment $(20 \times 20 \times 20 \mathrm{~cm})$ was composed of $2 \mathrm{~mm}$ stainless steel rods spaced $1 \mathrm{~cm}$ apart. These compartments were separated by a guillotine door $(5 \times 5 \mathrm{~cm})$. For acquisition trial, mice were initially placed in the illuminated compartment and the door between the two compartments was opened $10 \mathrm{~s}$ later. When mice entered the dark compartment, the door automatically closed and an electrical foot shock $(0.5 \mathrm{~mA})$ of $3 \mathrm{~s}$ durations was delivered through the stainless steel rods. One hour before the acquisition trial, mice were administered pseudocoptisine $(1.0,2.0,5.0,10.0 \mathrm{mg} / \mathrm{kg}$, p.o. $)$ or tacrine $(10.0 \mathrm{mg} / \mathrm{kg}$, p.o.). After a delay of $60 \mathrm{~min}$, amnesia was induced in mice with scopolamine $(1.0 \mathrm{mg} / \mathrm{kg}$, i.p.) given subcutaneously. Control animals were administered $10 \%$ Tween 80 solution only. Twenty-four hours after acquisition trial, the mice were again placed in the illuminated compartment for the retention trials. The time taken for a mouse to enter the dark compartment after door opening was measured as latency times in both acquisition and retention trials. If the mice stayed in the light compartment for $180 \mathrm{~s}$, it was concluded that the mice had memorized the passive avoidance training after training trial. $^{15)}$

Morris Water Maze Task A spatial test was performed by the method of Morris with minor modification. The water maze is a circular pool $(90 \mathrm{~cm}$ in diameter and $45 \mathrm{~cm}$ in height) with a featureless inner surface. The pool was filled to a depth of $30 \mathrm{~cm}$ with water containing $500 \mathrm{ml}$ of milk $\left(20 \pm 1{ }^{\circ} \mathrm{C}\right)$. The pool was divided into four quadrants of equal area. A white platform $(6 \mathrm{~cm}$ in diameter and $29 \mathrm{~cm}$ high) was then placed in one of the pool quadrants. The first experimental day was dedicated to swimming training for $60 \mathrm{~s}$ without the submerged platform. During the five subsequent days, the mice were given two daily trials with an intertrial interval of $30 \mathrm{~min}$ in the presence of the platform in place. When a mouse located the platform, it was permitted to remain on it for $10 \mathrm{~s}$. If the mouse did not locate the platform within $120 \mathrm{~s}$, it was placed on the platform for $10 \mathrm{~s}$. The animal was taken to its home cage and was allowed to dry up under an infrared lamp after each trial. ${ }^{16)}$ During each trial session, the time taken to find the hidden platform (latency) was recorded. One day after the last training trial sessions, mice were subjected to a probe trial session in which the platform was removed from the pool, allowing the mice to swim for $120 \mathrm{~s}$ to search for it. A record was kept of the swimming time in the pool quadrant where the platform had previously been placed. Pseudocoptisine $(2.0 \mathrm{mg} / \mathrm{kg}$, p.o. $)$ or tacrine $(10.0 \mathrm{mg} / \mathrm{kg}$, p.o. $)$ was given $1 \mathrm{~h}$ before the first trial session at every consecutive day. Memory impairment was induced in mice with scopolamine $(1.0 \mathrm{mg} / \mathrm{kg}$, i.p. $)$ at $60 \mathrm{~min}$ after treatment of test samples. Control group received $10 \%$ Tween 80 solution only.

Ex-Vivo Study of Brain Acetylcholinesterase The most effective doses as determined by the passive avoidance task were chosen. Mice were orally administered vehicle and pseudocoptisine $(2.0 \mathrm{mg} / \mathrm{kg}$, p.o. $)$. Animals were decapitated $30 \mathrm{~min}, 1 \mathrm{~h}, 3 \mathrm{~h}, 6 \mathrm{~h}$, or $12 \mathrm{~h}$ after each administration, and brains were removed to assay AChE activity which was assessed as described above for the in vitro method.

Statistical Analysis The results are expressed as mean values \pm S.D. Statistical analysis was performed using oneway ANOVA. $p<0.05$ was considered statistically significant.

\section{RESULTS AND DISCUSSION}

Although there have been a number of reports on the designing and development of synthetic AChE inhibitors, ${ }^{17-19)}$ that were necessary for those other studies, which have been reported the AChE inhibitors derived from medicinal plants. ${ }^{20-22)}$ Repeated column chromatography led to the isolation of a powder compound, which was identified as pseudocoptisine (Fig. 1) by analyses of MS, NMR data, and comparison with those in the literatures. ${ }^{23)}$ Pseudocoptisine was found to inhibit AChE activity in a dose dependent manner with an $\mathrm{IC}_{50}$ value of $12.8 \mu \mathrm{M}$ with the independent of in-

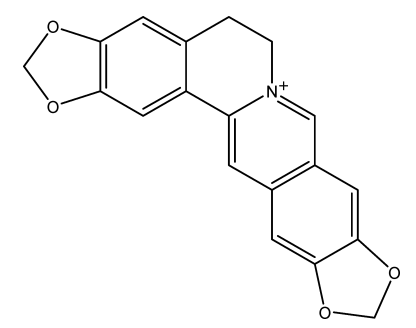

Fig. 1. Pseudocoptisine Structure 
cubation time. It suggests that pseudocoptisine inhibited AChE reversibly. Tacrine, which was used as positive control, exhibited AChE activity with $\mathrm{IC}_{50}$ value of $175.2 \mathrm{~nm}$. The kinetic analysis of the inhibition of the AChE activity of pseudocoptisine was performed. A reaction mixture, consisting of different concentrations of acetylthiocholine iodide either in the absence or presence of pseudocoptisine. The Michaelis-Menten constant $\left(K_{\mathrm{m}}\right)$ and maximum velocity $\left(V_{\max }\right)$ of AChE were determined by Lineweaver-Burk plots, using the GraphyPad Software Inc., U.S.A. The $K_{\mathrm{m}}$ value was significantly decreased by the addition of pseudocoptisine but the $V_{\max }$ was not changed (data not show). These results indicate that pseudocoptisine inhibited AChE activity in a competitive manner.

Since such AChE inhibitors have been used to reduce the cholinergic deficit in $\mathrm{AD}$, and based on the inhibition effect of pseudocoptisine on AChE, we assessed whether pseudocoptisine improves memory function by passive avoidance learning, which is largely dependent on long-term memory. When placed into the bright side of a step-through box, mice quickly entered the dark compartment. Mice were conditioned using a mild foot shock after entering the dark compartment and hesitated to re-enter the dark compartment when tested $24 \mathrm{~h}$ later. By using this shuttle box system, saline-treated control mice stay in the light compartment for $180 \pm 5 \mathrm{~s}$ after the passive avoidance training. Meanwhile, the mice given scopolamine $(1.0 \mathrm{mg} / \mathrm{kg}$ body weight) stayed in the light compartment for only $22 \pm 3 \mathrm{~s}$ before moving into the dark compartment. Thus, the step-through latency of the scopolamine-treated mice was significantly shorter than that of vehicle-treated control mice (Fig. 2, $p<0.05$ ). In tacrine plus scopolamine-treated mice, step-through latency was significantly greater than for scopolamine-treated mice $(152 \pm 5 \mathrm{~s}$ vs. $22 \pm 3 \mathrm{~s})$. Moreover, the reduction in stepthrough latency induced by scopolamine was significantly reversed by pseudocoptisine $(2.0,5.0 \mathrm{mg} / \mathrm{kg}$, p.o.; $p<0.05)$. However, at doses of 1.0 and $10.0 \mathrm{mg} / \mathrm{kg}$, this compound did not exhibit a much of significant effect. Latency time during the acquisition trial was not affected by any drug treatment (Fig. 2)

In further study, the effect of pseudocoptisine $(2.0 \mathrm{mg} / \mathrm{kg}$, p.o.) on spatial learning (long-term or short-term memory) was evaluated using the Morris water maze test. ${ }^{24}$ The saline-treated control group rapidly learned the location of the platform (Fig. 3A). The scopolamine-treated animals exhibited longer escape latencies (the time taken to find the platform) throughout training days than the vehicle-treated controls $(p<0.001)$. Pseudocoptisine $(2.0 \mathrm{mg} / \mathrm{kg})$ significantly attenuated the effects of scopolamine on escape latency $(p<0.05)$, as did tacrine $(p<0.05)$. On the day of probe testing, a significant group effect was observed on swimming times in the probe test (Fig. 3B). Swimming times within the platform quadrant for the scopolamine-treated group were significantly lower than those of vehicle-treated control group animals (Fig. 3B, $p<0.05$ ). Moreover, the shorter swimming times within the platform quadrant induced by scopolamine were significantly reversed by pseudocoptisine or tacrine $(p<0.05)$. In addition, the ex-vivo testing showed a significant group effects on AChE activity of pseudocoptisine $(2.0 \mathrm{mg} / \mathrm{kg})$ from 42.2 to $90.8 \%$ due to the sacrificed time of mice (0.5-12 h) (Fig. 4).

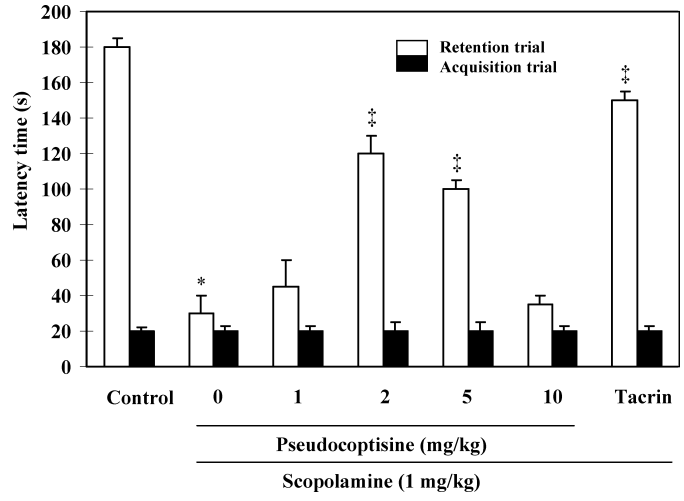

Fig. 2. Effect of a Single Administration of Pseudocoptisine on Scopolamine-Induced Memory Deficits as Determined by the Passive Avoidance Task

At $60 \mathrm{~min}$ before acquisition trials, pseudocoptisine $(1.0,2.0,5.0$ or $10.0 \mathrm{mg} / \mathrm{kg}$, p.o.), tacrine $(10.0 \mathrm{mg} / \mathrm{kg}$, p.o.) or vehicle (same volume of $10 \%$ Tween 80 ) solution was administered to mice. Memory impairment was induced by administering scopolamine $(1.0 \mathrm{mg} / \mathrm{kg}$, i.p.). Five different animals were used per treatment group. Acquisition trials were carried out $30 \mathrm{~min}$ after a single scopolamine treatment. Twenty-four hours after the acquisition trials, retention trials were carried out for $3 \mathrm{~min}$. Data represent means \pm S.E.M $(* p<0.05 v s$. vehicle control group, $\ddagger p<0.05 v s$. scopolaminetreated group).
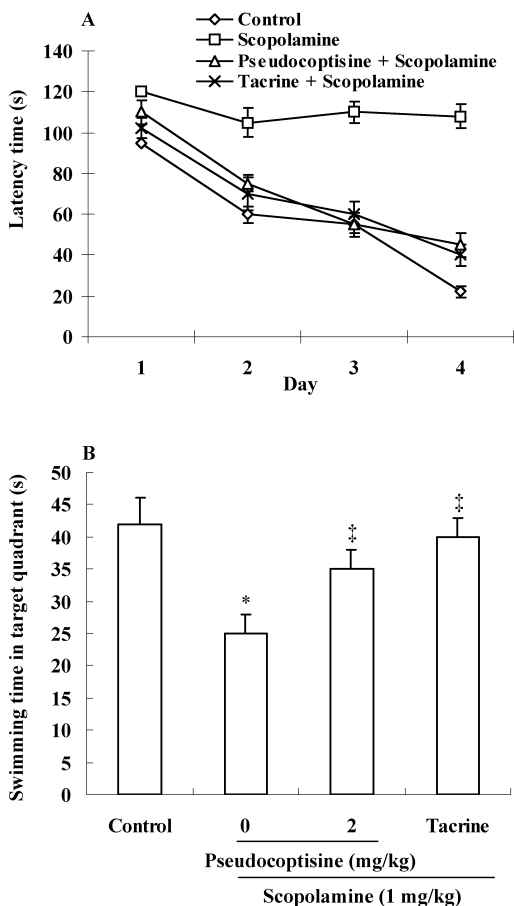

Fig. 3. Effect of Pseudocoptisine on Latency Time during the Training Trial Sessions (A), and on Swimming Time (B) during the Probe Trial Session of the Morris Water Maze Task in Scopolamine-Induced Memory Deficits Mice

At $60 \mathrm{~min}$ before training trial sessions, pseudocoptisine $(2.0 \mathrm{mg} / \mathrm{kg}$, p.o. $)$, tacrine $(10.0 \mathrm{mg} / \mathrm{kg}$, p.o.) or vehicle (same volume of $10 \%$ Tween 80$)$ solution was administered to mice. Memory impairment was induced by scopolamine treatment $(1.0 \mathrm{mg} / \mathrm{kg}$, i.p.). Five different animals were used per treatment group. The training trial and probe trial sessions were performed as described in Materials and Methods. Data represent means \pm S.E.M $(* p<0.05 v s$. vehicle control group, $\ddagger p<0.05 v s$. scopolamine-treated group).

As mentioned early, AChE inhibitors increased the availability of acetylcholine in central cholinergic synapses and are the most promising currently available drugs for the treatment of AD. ${ }^{25,26)}$ Scopolamine, which is a muscarinic receptor antagonist and can pass through blood brain barrier 


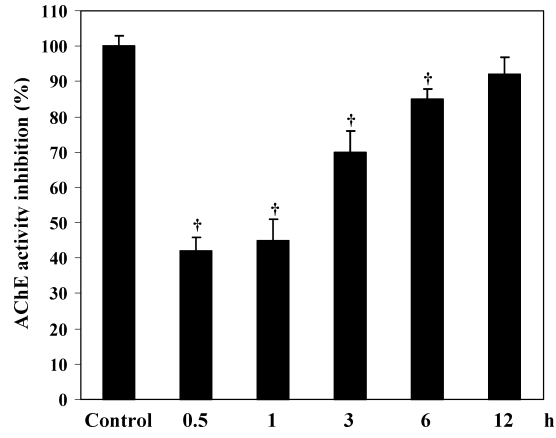

Fig. 4. Inhibitory Effect of Pseudocoptisine $(2.0 \mathrm{mg} / \mathrm{kg})$ on $\mathrm{AChE}$ in the Mice Whole Brain Homogenates

AChE activity was determined as described in Materials and Methods. Data represent means \pm S.E.M $(\dagger p<0.05 v s$. vehicle control group $)$.

causes amnesia in animals by blocking cholinergic neurotransmission. Cholinergic interneurons in the striatum are an even richer source of acetylcholinesterase and would also be affected strongly by such enzyme inhibitors. In this study, we examined the effects of pseudocoptisine on scopolamine-induced memory using passive avoidance and water maze task in mice. The passive avoidance is generally accepted as an indicator of long-term memory in animals, ${ }^{26}$ and the water maze-learning task was used to assess hippocampal-dependent spatial learning ability. ${ }^{24,27,28)}$ Pseudocoptisine treatment $(2.0,5.0 \mathrm{mg} / \mathrm{kg})$ reversed the deficits produced by scopolamine treatment in the comparison with vehicle-treated group on passive avoidance task. At the concentration of $2.0 \mathrm{mg} / \mathrm{kg}$, pseudocoptisine significantly shortened the escape latency, improved the swimming time within the zone of platform on water maze task. Also in the present study, pseudocoptisine could inhibit AchE activity in a dose dependent manner $\left(\mathrm{IC}_{50}=12.8 \mu \mathrm{M}\right)$. These suggest that ability to alleviate scopolamine-induced memory impairment or the anti-amnesic activity of this alkaloid is, in part, mediated by the AchE inhibition.

It would be interesting to indicate that quaternary nitrogen is necessary for strong activity in alkaloids possessing the benzylisoquinoline skeleton. ${ }^{9}$ ) In some species of Papaveraceae family, AChE inhibitory activity has been detected and has been traced to the benzylisoquinoline alkaloids present like berberine, ${ }^{29)}$ corynoline, protopine, palmatine. ${ }^{8,12)}$ The in vitro activity of berberine and protopine showed to be translated into effects since it improved scopolamine-induced amnesia in rats. ${ }^{12,30)}$ Thus, pseudocoptisine and some other constituents on Corydalis Tuber are able to play important role on the treatment of memory dysfunction of this plant.

In conclusion, based on the results of experiments, we found that pseudocoptisine had remarkable cognitive-enhancing activity. However, the more studies should be preserved if this compound may be offered as a useful therapeutic choice in the prevention of AD.

Acknowledgements This work was supported by a grant funded from the Korean Food and Drug Administration (2007).

\section{REFERENCES}

1) Selkoe D. J., Neuropathol. Exp. Neurol., 53, 438- 447 (1994).

2) Becker R., Giacobini E., Elble R., Mcllhany M., Sherman K., Acta Neurol. Scand. Suppl., 116, 19-32 (1988).

3) Bores G. M., Huger F. P., Petko W., Mutalib A. E., Camacho F., Rush D. K., Selk D. E., Wolf V., Kosley R. W., Davis L., Vargas H. M., J. Pharmacol. Exp. Ther, 277, 728-738 (1996).

4) Silman I., Sussman J. L., Curr. Opin. Pharmacol., 5, 293 -302 (2005).

5) Bae K. H., "The Medicinal Plants of Korea," Kyo-Hak Publishing Co., Seoul, 2002, p. 180.

6) Lin M. T., Chueh F. Y., Hsieh M. T., Chen C. F., Clin. Exp. Pharmacol. Physiol., 23, 738-742 (1996).

7) Orhan I., Şener B., Choudhary M. I., Khalid A., J. Ethnopharmacol., 91, 57-60 (2004).

8) Kim D. K., Lee K. T., Baek N. I., Kim S. H., Park H. W., Lim J. P., Shin T. Y., Eom D. O., Yang J. H., Eun J. S., Arch. Pharm. Res., 27, 1127-1131 (2004).

9) Houghton P. J., Ren Y., Howes M. J., Nat. Prod. Rep., 23, 181-199 (2006).

10) Sagara K., Ito Y., Ojima M., Oshima T., Suto K., Misaki T., Itokawa H., Chem. Pharm. Bull., 33, 5369-5374 (1985).

11) Matsuda H., Shiomoto H., Naruto S., Namba K., Kubo M., Planta Med., 54, 27-33 (1988).

12) Kim S. R., Hwang S. Y., Jang Y. P., Park M. J., Markelonis G. J., Oh T. H., Kim Y. C., Planta Med., 65, 218-221 (1999).

13) Saito S. Y., Tanaka S. Y., Tanaka M., Matsugana K., Li Y., Ohizumi Y., Biol. Pharm. Bull., 27, 1270-1274 (2004).

14) Ellman G. L., Courtney K. D., Andres V. J., Featherstone R. M., Biochem. Pharmacol., 7, 88-90 (1961).

15) Park C. H., Kim S. H., Choi W., Lee Y. J., Kim J. S., Kang S. S., Suh Y. H., Planta Med., 62, 405-409 (1996).

16) Kim S. R., Kang S. Y., Lee K. Y., Kim S. H., Markelonis G. J., Oh T. H., Kim Y. C., Cogn. Brain Res., 17, 454-461 (2003).

17) Carotti A., Candia M., Catto M., Borisova T. N., Varlamov A. V., Méndez-Álvarez E., Soto-Otero R., Voskressensky L. G., Altomare C., Bioorg. Med. Chem., 14, 7205-7212 (2006).

18) Rao C. S., Venkateswarlu V., Achaiah G., Bioorg. Med. Chem. Lett., 16, 2134-2138 (2006).

19) Andreani A., Granaiola M., Guardigli M., Leoni A., Locatelli A., Morigi R., Rambaldi M., Roda A., Eur. J. Med. Chem., 40, 1331-1334 (2005).

20) Khalid A., Haq Z., Ghayur M. N., Feroz F., Rahman A., Gilani A. H., Choudhary M. I., Steroid Biochem. Mol. Biol., 92, 477-484 (2004).

21) Houghton P. J., Agbedahunsi J. M., Adegbulugbe A., Phytochemistry, 65, 2893-2896 (2004).

22) Choudhary M. I., Devkota K. P., Nawaz S. A., Ranjit R., Rahman A., Steroids, 70, 295-303 (2005).

23) Al-Rehaily A. J., Sharaf M. H. M., Zemaitis M. A., Gao C. Y., Martin G. E., Hadden C. E., Thamann T. J., Lin F. T., Schiff P. L. J., J. Nat. Prod., 62, 146-148 (1999).

24) Morris R. G., J. Neurosci. Methods, 11, 47-60 (1984).

25) Giacobini E., Prog. Brain Res., 84, 321-332 (1990).

26) LeDoux J. E., Behav. Brain Res., 58, 69-79 (1993).

27) Blokland A., Geraerts E., Been M., Behav. Brain Res., 154, 71-75 (2004).

28) Barnes C. A., Danysz W., Parsons C. G., Eur. J. Neurosci., 8, 565571 (1996).

29) Kuznetsova L. P., Ikol'skaya E. B., Sochilina E. E., J. Evol. Biochem. Physiol., 38, 35-39 (2002).

30) Peng W. H., Hsieh M. T., Wu C. R., Jpn. J. Pharmacol., 74, 261-266 (1997). 